40-1| 2015

Enjeux contemporains en études irlandaises - In Memoriam Paul Brennan

\title{
Charlotte McIvor and Matthew Spangler (eds), Staging Intercultural Ireland. New Plays and Practitioner Perspectives
}

\section{Alexandra Poulain}

\section{(2) OpenEdition}

Electronic version

URL: http://journals.openedition.org/etudesirlandaises/4688

DOI: $10.4000 /$ etudesirlandaises. 4688

ISSN: 2259-8863

Publisher

Presses universitaires de Rennes

Printed version

Date of publication: 30 June 2015

Number of pages: $378-380$

ISBN: $978-2-7535-4082-8$

ISSN: 0183-973X

\section{Electronic reference}

Alexandra Poulain, «Charlotte Mclvor and Matthew Spangler (eds), Staging Intercultural Ireland. New Plays and Practitioner Perspectives », Études irlandaises [Online], 40-1 | 2015, Online since 30 June 2015, connection on 04 May 2019. URL : http://journals.openedition.org/etudesirlandaises/4688

This text was automatically generated on 4 May 2019.

(c) Presses universitaires de Rennes 


\title{
Charlotte McIvor and Matthew Spangler (eds), Staging Intercultural Ireland. New Plays and Practitioner Perspectives
}

\author{
Alexandra Poulain
}

\section{REFERENCES}

Charlotte MCIVOR and Matthew SPANGLER (eds), Staging Intercultural Ireland. New Plays and Practitioner Perspectives, Cork, Cork University Press, 2014, 390 p., ISNB 978-1-78205-104-6.

1 Among the host of new anthologies of Irish plays which have appeared recently, Staging Intercultural Ireland is of particular interest because of its focus on inward-migration in Ireland during and after the Celtic Tiger and its impact on theatrical practises and forms, as well as on the many ways in which it challenges traditional definitions of Irishness. The volume contains a substantial introduction which clarifies the project of editors Charlotte McIvor and Matthew Spangler, eight plays by native Irish or migrant playwrights which premiered between 2001 and 2013, each preceded by a short introduction, and six interviews with theatre and dance practitioners whose work has addressed issues of migration and intercultural encounters, and created a space for migrant artists to express their experience in Ireland, namely Bairbre Ni Chaoimh of Calypso Productions, John Scott, founder of Irish Modern Dance Theatre (now John Scott Dance), Declan Gorman and Declan Mallon of Upstate Theatre Project, Anna Wolf, Kasia Lech and John Currivan of Polish Theatre Ireland and performers Alicja Ayres and José Miguel Jimenéz.

2 Nicola McCartney's Cave Dwellers (first produced by 7:84 Scotland Theatre in 2001) follows the physical and emotional tribulations of three asylum-seekers of undefined nationality as they wait in vain for a smuggler to take them overseas to their chosen destination, in a tragic replay of Waiting for Godot. Their stories are counterpointed with the narrative of a 
fourth Man as he answers the questions of unheard, unseen policemen or customs officers after nearly drowning in an attempt to land illegally.

In Hurl, first produced by Barabbas in 2003, Sara Brady stages a group of migrants of diverse origins languishing in the Asylum-Seeker Direct Provision Centre in Galway, who form a hurling team, persuade a drunken, defrocked priest to coach them and, against all the odds, end up winning the Provincial Club Final. The play oscillates between narrative and dramatic modes and, in keeping with Barabbas' emphasis on physical theatre, challenges actors to explore non-naturalistic ways of recreating the hurling games. The overall comic pattern of the play is undermined by the sombre ripples of rampant or overt racism which the players encounter, and which result in the team founder's deportation and imprisonment in his native Sierra Leone.

Ursula Rami Sarna's Orpheus Road, first produced in the Young Vic in London in 2003, in the only play in the collection which is set in Belfast, and addresses the notion of multiculturality in the context of the Troubles, returning to the period prior to 1998 . Building on the pattern of the cross-cultural romance which constitutes a sub-genre in its own right of Irish melodrama, it attempts to renew the genre by staging an encounter between a Catholic boy from a staunchly Republican family and a girl whose mother is a white South African, who frequents a Protestant school but has no religious affiliation. While she questions the validity of the violence they are confronted to when the art gallery they are visiting is bombed (by mistake), the boy argues that it is necessary to look at "the bigger picture", thus clearly repeating his Republican father's rhetoric; yet this is precisely what the play fails to do, ultimately condoning the hackneyed gospel that "violence is stupid" and picturing Republican activists as terror-wielding idiots without providing a larger context for isolated eruptions of violence.

Donal O'Kelly's The Cambria, written for Calypso and first produced in 2005, is an extraordinary multiple-role epic for two actors recounting Frederick Douglas' voyage to Ireland on board The Cambria in 1845. As an escaped slave, Douglas travels incognito but is soon exposed, and the play explores the range of responses to this early-day "asylumseeker", implicitly questioning contemporary Ireland's attitudes to new migrants.

Bisi Adigun's Once Upon a Time \& Not So Long Ago, first presented as one piece in Dublin's O'Reilly Theatre in 2006 by Adigun's company Arambe, consists of two independent yet related acts each made of a succession of brief sketches. In Once Upon A Time a narrator seconded by a group of performers relates a series of humorous, often ironic West African tales, which though firmly anchored in African culture resonate indirectly in the context of contemporary Ireland. In Not So Long Ago, the Director of an intercultural theatre company (obviously based on Adigun himself) talks to the TV host on the "Great great show" and introduces a number of short sketches based on real-life encounters between migrants and native Irish people, illustrating the difficulties and prejudices to which migrants are exposed on a daily basis.

7 In Mushroom (first produced by Storytellers Theatre Company in 2007), Jason King stages the experiences of five migrant workers from Romania and Poland and one young Irish man with Romanian origins as they struggle to make sense of their lives, experimenting with the stage potential of linguistic barriers, multiple languages and unconventional versions of English.

8 This preoccupation with language is also central to Rosaleen McDonagh's Rings (2010), which departs from the other plays in the collection by focusing on the traveller 
community in Ireland, and specifically on the character of Norah, a deaf traveller girl who challenges the culture and traditions of her community when she becomes a successful boxer. The play confronts the interspersed monologues of Norah and her father, with Norah signing throughout since, as the inaugural stage direction informs us, "sign language is her only method of communication".

The last play in the collection is Mirjana Rendulic's semi-autobiographical monologue Broken Promise Land (first presented at Theatre Upstairs, Dublin, in 2013) which retraces a year in the life of Croatian "Stefica" during her brief career as a lap dancer in Italy, Japan and Ireland, raising uncomfortable questions about the status of migrant workers in Ireland and the degree of autonomy or exploitation of sex workers around the world.

This anthology gathers some of the most exciting new work in Irish theatre in recent years, and demonstrates the extent to which multicultural encounters and artistic collaborations can revitalise dramatic forms, languages and themes and challenge dominant definitions of Irishness. In the Introduction and interviews which frame the anthology, the editors demonstrate an acute awareness of the material conditions of production of theatre and of the way in which theatre depends on political intervention (several of the companies involved in the production of the plays gathered here have since then disappeared due to lack of subsidy), and also repeatedly show how theatre in Ireland remains a privileged political forum where the self-image and values of the nation are elaborated, contested and constantly remoulded.

\section{AUTHORS}

\section{ALEXANDRA POULAIN}

Université Lille 3 